\title{
Towards a Carbon-Neutral State: International Progress, National Risks and Coping Strategies
}

\section{Manqing Cheng}

Department of Politics and International Relations, University of Auckland, Auckland 1010, New Zealand.

\begin{abstract}
Climate change is a major social, economic and environmental challenge facing all countries in the world today. It has increasingly become a priority on the agenda of international relations. This article outlines major developments in international climate action during and after the pandemic. The article identifies the global trends of carbon action on the countries' agendas for sustainable development in the near future, including accelerate the implementation of mature zero-carbon solutions and promote zero-carbon technology. It then presents risks in tackling the global climate crisis collectively confronted by the international community at present, such as economic slowdown, energy security, carbon financing, price inflation, carbon barrier, carbon trading and carbon debt. With these common dilemmas in mind, the article sums up by proposing multiple possible directions towards reducing emissions and putting forward some community strategies for New Zealand to implement. These include promote the electrification of transportation and establish green infrastructure, consumption, financial, technology and industrial systems. This article aims to inform on the debate about current challenges in building a sustainable and resilient carbon-neutral state in the wake of global public crisis by analysing global developing trends in addressing climate change, as well as to provoke thinking on potential options for government to enable net zero carbon and new energy future.
\end{abstract}

Key Words: Global climate governance; COVID-19; Carbon neutrality; Paris Agreement; European Union; Carbon emission reductions

\section{Introduction}

COVID-19 has had a profound impact on global climate governance and implementation of carbon neutrality beyond 2020. Positively, countries call for the reduction of public activities, resulting in a significant drop in the demand for transportation and a downward trend in global carbon emissions. The pandemic has also promoted the research and development of internet, artificial intelligence and information technology and means, which is conducive to new breakthroughs in the field of renewable energy (OECD, 2021). However, the negative cannot be ignored. The pandemic has hit many industries, including manufacturing and service industries. Losses caused by this have posed a crisis to governments in terms of fiscal budgets and monetary policies. Governments have had to maintain or increase imports of medical equipment, supplies and expenditures on health care. This has weakened the ability of countries to raise funds to combat climate change, delaying investment in renewable energy projects, and thus undermining the implementation of climate plans. Facilitate the transition to a carbon neutral public sector and a low carbon economy is a kernel component for all governments to address the climate crisis. It is particularly urgent and necessary to have a clearer and deeper understanding of the global climate governance situation in the post-pandemic era and further improve the related mechanism. In this context, starting from the development of global practices, this article first sorts out the climate propositions and actions of major economies in the world during and after the pandemic. The second section discusses the new focus in achieving net-zero under the new situation and the main problems and dilemmas of climate governance faced by all governments. The third section provides references for the direction and solutions of New Zealand's national carbon neutrality in the post-pandemic era. Majority of the literature focus on possible actions, while this article not only touches on the policy alternatives, but contributes more in terms of 
recognizing future trends and potential risks in the progress of practicing carbon mitigation, offering an early view of issues.

\section{Climate Propositions and Actions of Major Economies on Carbon Neutrality}

Sovereign states play an indispensable role in the UN climate governance framework, whether within or outside the framework. The European Union, the United States and China are important players in global climate governance. Their propositions and actions are of great significance for promoting the process of carbon neutrality, exploring a new way out, and pushing global climate governance to a new level. On 11 December 2019, the European Commission released the European Green Deal, aiming for the European Union to become the first climate-neutral bloc in the world by 2050. On January 14, 2020, the European Commission presented the European Green Deal Investment Plan (the Sustainable Europe Investment Plan), mobilizing at least EUR 1 trillion in sustainable investments over the next decade to achieve the goals set by the Green Deal (Rădulescu \& Pascu, 2020). NextGenerationEU is a temporary recovery instrument of $€ 800$ billion, 37\% of which will be spent in fighting climate change for "a greener, more digital, more resilient Europe" (ICPDR, 2020; European Commission, 2021). The UK has launched the Clean Growth Fund of $£ 40$ million venture capital to support green start-up companies in clean, low-carbon technologies (UK Government, 2020). The Moon administration in July 2020 has proposed spending 160 trillion won (\$130 billion) on the Korean New Deal to create 1,901,000 jobs by 2025 based on two pillars of the Green New Deal and the Digital New Deal (MoEF South Korea, 2020). In September 2020, China has announced that the country will strengthen its 2030 climate target (Nationally Determined Contribution), peak emissions before 2030 and aim to achieve carbon neutrality before 2060 (Xi, 2020). Japan plans to conclude its revision of Basic Energy Plan by mid-2021. On January 20, 2021, former U.S. Secretary of State John Kerry assumed the first Special Presidential Envoy for Climate and a member to sit on the National Security Council entirely dedicated to climate change (State Department, 2021). In late March 2021, President Biden unveiled a USD 2 trillion infrastructure investment plan ("The American Jobs Plan") that would accelerate climate action. In April 2021 at the Leader's Climate Summit, President Biden announced a strengthened Paris Agreement target - an NDC of reducing emissions by 50-52\% below 2005 levels by 2030 (White House, 2021a; White House, 2021b). These carbon-neutral commitments and green stimulus packages will not only contribute to post-pandemic economic recovery, but will also propel the global economy into a new phase of greater sustainability, inclusiveness and resilience.

\section{Key Trends to Accelerate Carbon Neutral Deployment}

Thus far over 100 countries have set or are considering net-zero emissions or neutrality targets (van Soest et al., 2021). From the perspective of the carbon neutral strategies of major powers, there are several primary actions in common can be expected from most governments around the world in the near future:

Firstly, accelerate the implementation of mature zero-carbon solutions. These include carrying out a coal phase-out agenda, phasing out natural gas heating, building a number of zero-carbon power generation installations, and improving energy efficiency in the industry. At the International Energy Agency's (hereafter IEA) Clean Energy Transitions Summit in July 2020, ministers from 40 advanced and emerging economies, representing almost $80 \%$ of global energy consumption and carbon emissions, highlighted the importance of finding ways to support clean energy transitions including the need for greater innovation in areas such as hydrogen, the importance of inclusive and equitable recoveries, and how to make the electricity sector more resilient and sustainable (IEA, 2020). McKinsey (2019, p.4) forecasts that renewable generation will meet $50 \%$ of world electricity demand by 2035. IEA (2019) projects renewables will reach two-thirds of the worldwide electricity generation by 2040. The improvement of energy efficiency will be mainly concentrated in transportation, construction, and manufacturing sectors, which provides opportunities for technological innovation in smart homes and smart buildings.

Secondly, promote zero-carbon technology. This includes directing the public and private sectors to step up research and development in key technologies such as energy storage, sustainable fuels, hydrogen energy, and carbon capture, utilization, and absorption. Lithium-ion battery technology is likely to dominate the electric vehicle market over the next decade, and beyond 2030, more potential technologies will surpass the limits of lithium-ion battery technology. Hydrogen development will also accelerate. Japan unveiled a basic 
hydrogen strategy as early as 2017 aiming to import about 300,000 tons of hydrogen in 2030. In June 2020, Germany issued its National Hydrogen Strategy, showing its willingness to take a leading role in the production of green hydrogen. The European Commission presented the "Hydrogen Strategy for a climateneutral Europe" on July 8, 2020 and announced to invest up to $€ 470$ billion in renewable hydrogen by 2050 . Canada and China are also formulating blueprints for hydrogen energy development.

\section{Dilemmas to Face at Present and Potential Risks to Tackle in the Future}

The global spread of the pandemic since 2020, on the one hand, highlights the reality of human solidarity and the importance of collaborative international governance, and on the other hand, exposes the shortcomings of the existing global governance system. In tackling the global climate crisis, the international community are facing the following three common dilemmas.

The first is the conflict between the chronic nature of the global climate crisis and the demands of short-term domestic political interests. The non-traditional security issues represented by climate change are characterized by their long-term, gradual and dispersive impacts. In the traditional geopolitical rivalry, the climate issue has not been included in the national core security strategy. International climate negotiations are mainly a process of national interest game around carbon emission space. Although countries have reached consensus on issues such as climate response and sustainable development, they are unwilling to narrow their own economic development space by limiting greenhouse gas emissions, and often hope that other countries can shoulder more responsibility. While extreme weathers and the failure to mitigate and adapt to climate change emerge as the most likely and most serious long-term risks globally, countries are most concerned about their short-term risks, namely economic confrontation and domestic political polarization. Leaders' demands for political re-election determine that their domestic policies still focus on immediate core interests such as economic development and social stability. Political parties usually emphasize employment and welfare issues that voters concern most and put the long-term impact of climate change on the back burner. Typically, the US climate diplomacy has suffered plenty twists and turns due to the two-party race.

The second is the contradiction between the conductance of the climate crisis and the fragmentation of global climate governance. The global climate change is endogenously related and conductive. Several direct risks first trigger the climate crisis, and then form a transmission pathway through endogenous intercorrelation, which will lead to the worsening of the "cascade" of crises, and then have a chain reaction at various levels including economy, society, culture, ecology and politics. However, corresponding to the systemic threat of climate crisis, with the increase of all kinds of institutions and actors involved, global climate governance presents a development trend of a fragmented mechanism complex. Fragmentation does not necessarily mean the failure of governance, but the effectiveness depends on the degree of interaction between the core system and other institutions and norms, as well as the ability of coordination and integration among the institutions. The emission reductions and funding gap caused by the US withdrawal from the Paris Agreement is difficult for other countries to make up for. As a climate pioneer, the European Union has never given up its ambition to lead global climate governance, but it is also constrained by its economy, refugee issues and internal contradictions.

Third, the heterogeneity of the impact of climate change and the handicap of coping ability in the NorthSouth division are difficult to reconcile. At present, the lagging capacity of developing countries to tackle with the climate crisis has not been fundamentally improved. When a climate disaster strikes, its fragile socio-economic system will suffer more severe damage, which in turn will trigger a series of subsequent systemic social, economic and cultural declines. Although the Paris Agreement (2015) explicitly states that "Developed country Parties shall provide financial resources to assist developing country Parties with respect to both mitigation and adaptation in continuation of their existing obligations under the Convention" (article 9, para 1), results have not been encouraging. The US $\$ 100$ billion a year pledged by developed countries was only in the president's proposal, not in the official text of the Paris Agreement, and therefore not legally binding. In order to achieve the global $2^{\circ} \mathrm{C}$ target, developing countries need financial support of 300 to 1 trillion US dollars per year, but the Madrid Climate Conference in 2019 has not reached an agreement on the amount of aid beyond 2020. There are financing mechanisms such as the Global 
Environment Facility and the Green Climate Fund. However, due to the limited scale of funds, it cannot provide vigorous financial support, leading to the related climate action has also been delayed.

Achieving carbon neutrality is not only a matter of technology, energy, environment, but also an economic and social change with broad and profound impact. It is certain to have a significant impact on the development of New Zealand's economy, industry, technology, investment, finance and other aspects in the coming decades. Promoting carbon neutrality is a systematic project involving government, enterprises and residents, as well as energy, transportation and other sectors. If the relationship between development and emission reductions, overall and partial, short-term interests and long-term growth, and costs and benefits cannot be effectively handled in the process, a number of adverse effects may arise. Therefore, before putting forward measures, it is necessary to be vigilant against with potential risks.

\section{Risk of Economic Slowdown}

International experience shows that a country's carbon emissions are closely related to its economic development model and stage. From the perspective of climate economics, if radical measures are taken, the related high-carbon industries and enterprises will be impacted, resulting in the loss of investment, employment, and trade, and thus the loss of GDP. Internationally, the economic growth rate of most countries has slowed down after the peak emissions. Germany, for example, reached its peak emission in 1990, when GDP growth was 5.3\% year on year, the highest in two decades. After a wobbling retreat in 1991, annual growth averaged about $1.9 \%$ over the next decade, down from an average of $2.3 \%$ in the decade before the peak emission. The U.S. reached its peak emission in 2007, and then its economic growth tended to decline, with the average annual GDP growth rate dropping to 2.3\% from 2010 to 2019, lower than that of 3.36\% from 1997 to 2006. After the peak emission in Brazil in 2014, the economic growth rate is lower than that before the peak emission. After Japan reached its peak in 2012, its economic growth rate fluctuated in a narrow range, with per capita GDP falling. In 2001, the U.S. withdrew from the Kyoto Protocol on the grounds that reducing greenhouse gas emissions will affect the economic development of the U.S. and developing countries should also undertake the obligation to reduce and limit emissions, then the US economy ushered in a rapid development in the following four years.

\section{Risk of Energy Security}

From the perspective of energy supply, it is imperative to build a new power system with new energy as the main body. Problems such as the lack of new energy business models, the mismatch of upstream and downstream production capacity, and the dependence on the import of key raw materials are prominent. At the technical level, there are still obvious shortcomings, which are difficult to be solved in the short term, and it is unable to meet the huge and continuously growing supply demand of the energy and power industries. In the process of promoting carbon neutrality, if not considering the types of energy, the way and efficiency of energy utilization, the adaptability of enterprise and market, a sweeping non-discretionary "decoalification" and "deoiling" will result in an insufficient power supply when investment in coal and traditional fossil fuels cannot keep up with and is being withdrawn too quickly, while new energy supplies cannot fill the vacancy. In addition, power generation of new energy has a strong volatility, instability, randomness, and intermittency. The access of a large proportion of new energy will have a huge impact on the safe and stable operation of the overall power system, and the risk and vulnerability of fluctuations of power grid will increase. Once there are large areas of extreme weather that last for a long time, the probability of large-scale power interruption and even system collapse will increase. On 28 September 2016, South Australia, where new energy power generation accounts for $48 \%$, suffered five system faults within 88 seconds under the influence of extreme weather including thunderstorms, resulting in six voltage disturbances, nine of the 13 wind farms off-line, and a loss of $445 \mathrm{MW}$ of generation, which evolved into a state-wide blackout lasting 50 hours (AEMO, 2016).

\section{Risk of Carbon Financing}

Advancing emission cuts will require massive investments in areas such as energy and infrastructure. According to International Renewable Energy Agency (hereafter IRENA) (2017), "around USD 3.5 trillion in energy sector investments would be required on average each year between 2016 and 2050, compared to 
USD 1.8 trillion in 2015" (p.8) and "cumulative additional investment in low-carbon technologies would be required to amount to USD 29 trillion over the period to 2050" (p.10) to limit the rise in global temperature to well below two degrees Celisius $\left(2^{\circ} \mathrm{C}\right)$, as set out in the Paris Agreement. The European Green Deal aims to raise 1 trillion euros for green investment over the next 10 years; the U.S. is planning a $\$ 2$ trillion jobs, infrastructure and green energy proposal to combat climate change; and the UK believes that reaching net zero emissions by 2050 could cost up to $£ 50$ billion each year by 2050, which translates into $1-2 \%$ of GDP per year (Stein et al., 2021; Imperial College London \& LSE, 2021). These investment needs generally confront a huge gap; the lack of funds has become a major obstacle to the energy transition strategy in many countries. Developed countries are required under the Paris Agreement to provide financial and technical assistance to developing countries, but it is now likely to be more difficult to deliver. Domestic capital alone may not be enough for such a large investment. But in a global shortage of green investment, countries must offer higher and more stable returns if they are to attract international capital.

\section{Risk of Price Inflation}

The increase in the proportion of clean and low-carbon energy may lead to an increase in the price of energy with electricity as the core. According to IRENA (2021), costs for renewable technologies continued to fall year-on-year and the share of renewable energy that had lower costs than the cheapest fossil fuel option increased significantly. But from the system as a whole, the new energy did not achieve a real sense of "fair price". The increasing investment in supporting power grid construction, dispatching and operation optimization, backup services, capacity compensation and other auxiliary services will raise the cost of the entire power system, which will eventually be paid by the end users. High prices are certainly about more than renewables, but there is some truth to these claims. For example, in Germany, on the monthly electricity bill in 2019 for an average German household, "while the nominal price of supply, distribution, and grid fees grew by 11 percent since the reference year, that of taxes, levies, and surcharges grew by 293 percent" (CLEW, 2020). This is partly caused by the substantial increase in the renewable energy surcharge, for which households were liable to pay 8.2 billion euros out of the total 22.7 billion euros in 2019 that is equivalent to more than a third of the country's power bill paid by private customers but account for less than a quarter of consumption. As Refinitiv reveals, in early 2021, "power prices in Japan have been volatile as the country uses more renewable energy in the wake of the Fukushima disaster in 2011 and the move towards carbon neutral economy in 2050". To reduce carbon emissions, in addition to increasing carbon sink, we have to rely on the development of carbon capture, utilization and storage (CCUS), carbon trading, carbon tax and other market-based emission reduction tools. The utilization of these technologies and market tools will also increase the production cost of enterprises. Possible administrative curbs on production can lead to higher prices for some commodities as well. In order to achieve carbon neutrality, several high-energy consuming manufacturing industries such as electrolytic aluminium and cement may face the pressure of administrative limits in terms of production, so the supply will be compressed. The resulting gap between supply and demand will lead to the rise of the corresponding product prices and the upward trend of producer price index.

\section{Risk of Carbon Barrier}

Future carbon emission is not only an environmental issue, but also a new global identity and a means of game of huge national political and economic interests. In order to meet the requirements of domestic environmental groups and protect their own industries, some developed countries are gradually connecting carbon emission reductions with trade. On 10 March 2021, the European Parliament voted to adopt the Carbon Boundary Adjustment Mechanism. Under the resolution, goods from countries exporting to the EU that do not comply with rules on greenhouse gas emissions will be subject to Border Tax Adjustment or the purchase of emission allowance. This is the EU version of carbon tariffs. The EU border levy is planned to be piloted in steel, cement and electricity, which would be applied in full from 2026 after a transitional implementation from 2023 (Abnett, 2021). The decision, if carried out, could set the stage for a "carbon barrier" or encourage more countries to follow suit. In March 2021, the Office of the U.S. Trade Representative stated that it would consider carbon border adjustments. The main consideration of formulating carbon tariff is to protect the competitiveness of high-emission industries in domestic. The design of carbon tariff follows the ideas of anti-dumping and countervailing, which is essentially a new type of trade protectionism. UN Climate Change Conference is the main platform for global climate negotiations, 
and documents such as the United Nations Framework Convention on Climate Change, Kyoto Protocol, and the Paris Agreement serve as the basic framework for global institutional arrangements in reducing emissions. Voluntary or Verified Emission Reduction is the main constraining mechanism. The legal structure promulgated in the Paris Agreement is universal, yet the attainment of the pledged contributions is not compulsory, which continues the principle of soft restriction. After the implementation of the EU carbon tariff, if the U.S. also launches similar measures, it may form a way with the market and industry emission reductions as the framework and the tariffs as restraints, which will have impact on the above frameworks and constraining mechanisms. Unlike traditional tariffs, carbon tariffs do not impose taxes on all exports to the EU indiscriminately. Instead, they are highly specific, targeting only those goods that the EU considers having failed to produce adequate emissions, or those from countries that have failed to reduce emissions. This has a stronger implication of unilateral constraints.

\section{Risk of Carbon Trading}

The main function of the carbon market is to trade greenhouse gas emission rights and promote energy conservation by limiting the total amount and adjusting the quota. It involves core issues such as carbon pricing and market mechanism. As of 31 January 2021, there are 24 emissions trading systems in force, with another eight are under development (ICAP, 2021). Emissions trading operates at every level of government from supranational to local, accounting for 54\% of global GDP, $16 \%$ of global GHG emissions, and almost one third of the world population (ICAP, 2021). However, there is no unified global trading system. Carbon pricing and carbon trading patterns under different trading systems differ greatly. Companies can move to countries where carbon prices are lower, or to places only with a carbon tax but no carbon trading in order to cut costs. Importing countries may also carry out anti-dumping and countervailing investigations and impose punitive carbon taxes on related commodities on the grounds that the carbon pricing of exporting countries is too low, and the carbon trading means are unreasonable and opaque. For a country, carbon price is too low to constrain emissions, while high price will limit economic growth, thus leading to relatively narrow space for relevant policies and carbon market to operate. From the perspective of climate governance, the competition between different trading systems also involves the competition for rules and shares, as well as a deeper competition for governance philosophy. European Union Emission Trading System is the earliest trans-national carbon trading system in the world. It implements 'cap and trade' principle and has crossborder trading experiences. It plans to overhaul its carbon market and invite companies and goods from more countries into its carbon trading scheme through carbon taxes on aviation and shipping (Morgan, 2020; Abnett, 2021). If the EU expands the scope of ETS and requires European exporters to participate in the EU's internal carbon trading, it will lead to the globalization of the EU's carbon trading rules and impact the fundamental structure of the global carbon market. Therefore, it cannot be ruled out that it will eventually expand the quasi-global trading system and occupy the high ground of global climate rules.

\section{Risk of Carbon Debt}

Carbon debt refers to the potential risk to financing if climate adjustment is not in place. This risk includes at least two aspects. On the one hand, international rating agencies may downgrade the sovereign credit rating of a country, as well as the credit rating of some institutions and private enterprises, due to their subjective views on the emission reduction work of a country, thus increasing financing costs. On the other hand, it gives a low rating to the carbon neutral bonds issued by a country, which directly affects the carbon financing of that country. In the meantime, a country's climate financing assistance to other developing economies in the form of debt will also be affected. In the 2020 study by the International Monetary Fund, it showed that climate change vulnerability and resilience have significant effects on government bond yields and spreads and on the probability of sovereign debt default, especially in developing countries. Another 2020 study by Cevik and Jalles (2020a) also found that countries with greater climate change resilience benefit from higher sovereign credit ratings, relative to countries with greater vulnerability to risks associated with climate change: from 1995 - 2017, an increasing of one percentage point in climate change resilience is associated with an improvement of 0.09 percent in sovereign credit rating; while an increase of one percentage point in climate change vulnerability results in a reduction of 0.23 percent in credit worthiness (p.12-13). Climate change vulnerability has no significant impact on credit ratings in advanced economies, however, the effects on sovereign credit ratings are much greater in the case of developing countries (Cevik \& Jalles, 2020a, p.13-14). A 2018 research commissioned by the United Nations 
Environment also revealed that climate vulnerability has raised the average cost of debt in developing countries by 117 basis points, which is equivalent to USD 40 billion in additional interest payments over the past 10 years on government debt alone. A 2021 research funded by the International Network for Sustainable Financial Policy Insights, Research and Exchange estimated that under higher emissions scenarios, 63 sovereigns experience climate-induced downgrades by 2030, which increase the cost of both public and private debt (Klusak et al., 2021, p.4-5). In the future, debt financing will be an important way for a country to achieve carbon financing, thus relevant risks should be paid attention to.

\section{Policy Implications for New Zealand in the Decades to Come}

Against this international backdrop of opportunities and challenges, it is far from enough to advance carbon emission reductions in a step-by-step manner as previous. Green economy is expected to become a new engine of national economic development and an important driving force of climate governance in the postpandemic era, which is worthy of New Zealand's attention. In the future, New Zealand needs to take stronger measures with greater determination and boldness. New Zealand needs to learn from international experiences, and in the next five to ten years, intensify support for key clean technologies, strengthen the institutional construction in carbon emission verification, legislation, and regulation. Specific wide-ranging measures can proceed with from several aspects.

First of all, promote the electrification of transportation. To achieve carbon neutrality in the transport sector, we need to optimize the transport structure, improve the efficiency of vehicles and the utilization of lowcarbon energy. To this end, New Zealand can increase investment in transportation electrification, enhance smart transportation, heighten the proportion of new energy vehicles, and encourage the innovation and application of biofuels, hydrogen fuels and other technologies in aviation and maritime fields. New Zealand can consider a phased deployment of new energy vehicles and hydrogen fuel-cell vehicles. For example, formulate a strategy like in a certain year, new energy vehicles sales should reach a certain proportion of the total sales of new cars; by a certain year, all vehicles in the public sector will be electrified, or new energy vehicles of newly added vehicles in the public sector in some region must not be lower than a certain proportion.

Secondly, the construction of sustainable transportation will require a corresponding green infrastructure system. Green infrastructure and the upstream and downstream of its industry chain include green transportation and green building. On the one hand, New Zealand should accelerate the green transformation of traditional infrastructure such as intercity high-speed railway and intercity rail transit, strengthen Electric Vehicle Charging Infrastructure, refuelling receptacle for Hydrogen fuel cell cars and other supporting infrastructure. On the other hand, 5G, artificial intelligence, internet of things, virtual reality, augmented reality, smart cities, core cloud, edge computing and big data can be used to improve the quality and efficiency of the corresponding industry. In this respect, several measures can be taken. First, the government can promote the sustainability orientation of its digital infrastructure. Second, New Zealand can improve the assessment system for the use of renewable energy in the digital infrastructure industry and consider the proportion of renewable energy in the data centre as one of the evaluation indicators. Third, the state can further improve the market mechanism for the use of renewable energy in the digital infrastructure industry, expand the scope of industry participation in the market-based transaction of renewable energy, and enrich the green certification trademarks mechanism. Fourth, the government should promote an incentive scheme of using renewable energy for digital infrastructure industry, guide capital flows and give full play to the role of public funds in leveraging low-carbon digital infrastructure. A green and intelligent building system needs to increase the application of energy-saving technologies in lighting and cooling, renovate existing buildings with energy saving and low carbon, raise green standards for new buildings, and encourage the utilization of clean power and natural gas in the building sector.

Third is the green consumption system. Reduce the needs for high-energy products from the demand side and fully stimulate the demand for green services is an important measure to achieve carbon neutrality. We need to strengthen the publicity of the concepts of low-carbon consumption and introduce incentive measures to guide and encourage people to buy energy-saving products and use intelligent technologies. The government can step up green purchasing power, share carbon footprint, further advocate a low-carbon 
lifestyle, expand the scope of green product procurement and extend the green procurement system to SOEs. New Zealand should strengthen the supervision of corporate emissions, upgrade disclosure standards for environmental information, guide enterprises to adopt low-carbon technologies, and support the development of new green industries by buying back old appliances and encouraging the consumption of energy-efficient home appliances. Local governments should introduce and implement measures to contribute to zero carbon according to their own situations. Local governments at all levels should take the lead in launching zero-emission plans in procurement, office work and services. Local governments can give priority to the purchase of low-carbon products and prohibit and phase out high-energy consumption and high-emission projects through progressively decreasing subsidies year by year. Through tax exemptions, loan guarantees and other green financial tools and policy incentives, local governments will shape the way of market financing for low-carbon projects.

Fourth is the green financial system. This includes not only green credit, green bonds, green funds, green insurance, but also carbon finance. New Zealand can foster a green trading market mechanism and enrich carbon financial products to identify prices and prevent and control risks. First of all, New Zealand should cultivate the innovation ability of generating multi-dimensional climate finance products and improve the carbon pricing mechanism, expand the scope of trading subjects in the carbon market, explore the trading of carbon financial derivatives represented by carbon futures, and strengthen international cooperation in the New Zealand carbon market. More strictly verify the carbon emission reports of the petrochemical, chemical, building materials, steel, non-ferrous metals, papermaking, electric power, aviation and other industries, formulate more comprehensive emission-monitoring plans, and gradually incorporate them into the carbon market. Secondly, New Zealand should create an effective management system to prevent systemic risks. The government can incorporate climate change into the monetary policy framework and financial macro-prudential assessment system, reduce the tolerance of non-performing green assets, develop ESG products, and issue environmental and climate risk rating. New Zealand can also establish a stress test tool in line with the financial institutions themselves. Therefore, it can first assess the loan and asset exposure of industries and regions that are greatly affected by global warming-related risks, and quantitatively analyse the credit, trading and market risks that risk exposure may bring to financial institutions. Thirdly, establish low-carbon transition or carbon neutrality funds. For example, the transition to low carbon will certainly accelerate "coal removal", and there will be a large number of workers to move out of the high carbon industry chain. This has a great impact on the West Coast, Nelson, Southland, Northland, Taranaki and other traditional coal-rich regions with relatively low economic development level, but high costs and more prominent transformation pains. The government could draw lessons from the European Just Transition Mechanism and set up relevant state-led fund. Through the special funds, national support will incline to these regions and communities, help to train the workers coming from the traditional energy industry and avoid drastic social unrest.

Fifth is the green technology system. Progress and innovation in energy technologies are the fundamental driving force for the energy transition. New Zealand should encourage research and development of lowcarbon technologies, strengthen independent innovation in this field, carry out green technology initiatives, and layout a number of forward-looking, strategic and disruptive science and technology projects. The state should create a strong and sustainable atmosphere of carbon-neutral technological innovation in the whole society. Carbon neutral technological innovation is accompanied by international competition, including but not limited to electricity storage, carbon capture and storage, thermal energy storage, nuclear fusion and fission technology, zero-carbon hydrogen, steel, cement and plastic production. In this regard, New Zealand needs to sum up its experience in the fields of fintech, healthtech, and agritech, as well as its shortcomings in the fields of engines and chips. To make up for the relevant energy $R \& D$ funds, the state needs to leverage the ambition of private enterprises, leverage industrial capital, stimulate the enthusiasm of public, support technological breakthroughs and achievement transformation, and apply enough innovative technologies to all sectors of society to serve the goal.

Sixth is the green industrial system. Carbon emission and industrial structure influence and interact with each other: industrial structural upgrading can reduce carbon emissions and improve carbon emission performance, while carbon emissions can promote industrial structure upgrading. For 2019, of tons of 
carbon dioxide equivalent in New Zealand agriculture made up 48\% and energy including transport $42 \%$ (MfE, 2021). The industry and transport sectors use the most energy, accounted for $34 \%$ and $36 \%$ of New Zealand's total energy consumption (Energy Resources Aotearoa, 2021). Within the industry sector, food, beverage, and tobacco product manufacturing, petroleum, chemical, polymer, and rubber product manufacturing, and metal product manufacturing are energy intensive and contribute more to carbon emissions. It is necessary to strictly control the new production capacity of the above-mentioned traditional high-energy consuming industries and optimize the existing production capacity. $60 \%$ of New Zealand's energy supply comes from oil, gas and coal (Energy Resources Aotearoa, 2021). There are over 30 fossil fuel electricity generation companies in New Zealand. Promote the transformation and upgrading of coal, oil, gas and other traditional fossil energy enterprises is one key aspect in building green industrial system. Carbon neutrality will force these oil and gas exploration and production companies to make profound changes. To accelerate the pace of transformation, enterprises need to achieve the following three points: first, carbon emissions should be included in all aspects of the company's operation, such as performance appraisal, investment decision, and asset allocation, to achieve low-carbon production and operation in all links; second, accelerate the adjustment of the enterprise's future business strategy, accelerate the layout and development of zero-carbon new energy businesses such as hydrogen energy, wind energy and solar energy, and strive to build itself into a provider of energy technology services, rather than a provider of energy resources, so as to achieve green energy products and services; third, digitization and low carbonization should be combined, and advanced technological means such as the internet of things, big data, cloud computing and artificial intelligence should be fully utilized to promote the transformation through innovation.

Provide substantial support for the development of green projects is another aspect in building green industrial system. It includes not only the development of emerging environmental protection industries, such as solar, wind and hydrogen, but also the green transformation of traditional industries such as steel, non-ferrous metals, paper, cement and building materials, as well as the acceleration of green agricultural development. New Zealand's transition to a zero-carbon economy will result in profound changes in its energy and industrial structure and will create huge new investment markets in renewable resources, energy efficiency, clean power generation, energy storage, hydrogen energy, CCUS and digitization. Greater government's support can go to risk rating, credit scale, capital markets and even fiscal taxation. The state should also accelerate the development of emerging industries such as modern service industry, high-tech and advanced manufacturing, bioindustry, and the digital economy, in order to gradually realize the decoupling of economic growth and carbon emissions.

Seventh, promote the development of two major markets for electricity and carbon trading. The large-scale development of new energy power generation depends on the construction of two markets. The first is the construction of electricity market. In the future, we should speed up the construction of electric power market, spot market, supplementary service market, possible capacity market, and introduce new energy market-oriented development policy, so that all kinds of electric power resources can realize their economic value in the market transaction to promote new energy in a wider range. The second is the construction of carbon trading market. Carbon trading market, as a low-cost policy tool for emission reductions, has been widely used in the world. It mainly functions in two ways: one is the incentive function, that is, stimulate the new energy industry or non-fossil energy industry to address the positive externalities of emission reductions; the other is the constraint function, that is, restrain the fossil energy industry to solve the negative externalities of carbon emissions and change the energy structure at the lowest cost and with the highest efficiency. In the future, the state can consider building a national unified trading market as appropriate and make systematic arrangements in emission allowances, enterprise participation scope, product pricing mechanism, to achieve the goal of optimizing resource allocation, managing climate risk, discovering emission price, and thus reduce carbon emissions.

Lastly, continuously reinforce and improve domestic climate and carbon legislation is the institutional guarantee for crisis response. At present, states are the core actors in the international climate crisis response and resource mobilization. Domestic climate change and carbon neutral legislation is the institutional basis for countries to cope with the climate crisis and ensure the long-term and stable development of relevant 
policies. The rights declaration issues such as emission rights in carbon trading also need the support of climate legislation. Although the 2019 United Nations Climate Change Conference in Madrid failed to reach the consensus of the international carbon market, but some countries and regions, such as Britain, Japan, Mexico, South Korea, the Philippines and California of the U.S., have passed the special law to respond to climate change, to provide a fundamental guarantee for its work in the legal system to carry out the climate crisis response. With the increasing threat of climate crisis, more and more countries and regions have started the process of climate legislation, integrating climate legal guarantee, institutional arrangement and public participation into the overall action. In December 2019, the EU launched the European Green Deal, which raised its 2030 greenhouse gas emission reduction target, and reduced its emissions by 50\% to 55\% compared with the 1990 level. To ensure the achievement of this goal, the European Commission in March 2020 proposed for the first European Climate Law, in the form of legislation for Europe's economy and society to become climate-neutral by 2050 . These policy changes will help achieve effective carbon pricing across the EU. It will also encourage consumers and businesses to make changes and increase public and private sector investment in sustainability-related fields in a powerful way.

\section{Conclusion}

The scale of the future risks will depend on the actions we take today to reduce emissions and build resilience. Only by constantly improving our ability to manage the climate crisis can we avoid the serious impact of the climate change in a limited time. Other than aforesaid strategies and policy recommendation, in the carbon neutral process, the state should also note few points.

Avoid aggressive carbon reduction measures. The benefits of taking action and the significant costs of inaction are recognized, however, there is no quick success for instant benefits. There are differences in regional development in New Zealand. Different regions have different basic conditions in economic development, industrial and energy structure. Carbon neutrality is a long-term goal that cannot be achieved overnight. Measures should be taken according to local conditions. In some areas, people's livelihood still depends on the production and consumption of high-carbon energy. While reducing high-carbon energy, local governments should adopt supportive social policies to prevent these people from falling into difficulties. Local governments should not significantly reduce the production and consumption of coal, oil and gas and other fossil fuels and engage in a carbon emission reduction race to attain early targets, leading to an energy shortage caused by excessive energy transformation and insufficient investment in fossil fuels. In the summer of 2020, an important reason for the regional rolling blackout in California was that the state did not realize the correct energy mix while substantially increasing the proportion of new energy generation and promoting energy transformation, which ultimately caused the lack of sufficient power resources. In order to achieve the target of "dual control" of energy and the task of "reducing coal" in 2020, the Chinese cities of Yiwu and Wenzhou in Zhejiang Province have introduced measures to limit the power consumption of government offices, public places and some enterprises under certain conditions.

Carbon neutrality will bring profound impacts and challenges to New Zealand's economy, energy, technology and policy system. Achieving carbon neutrality is a huge systemic project. It not only needs the change of ideology, the progress of technology, the innovation of business model, the support of policy and the guarantee of system mechanism, but also needs to adhere to the systematical thinking and break all kinds of barriers. Break barriers between energy companies and energy types. Under the traditional energy system, various types of energy such as coal, electricity, oil, gas and nuclear are separated from each other and each is fighting for itself. But New Zealand's energy resource endowment and national conditions determine that it is impossible to develop a single energy mode in the future. It is essential to complement each other with multiple energy sources to realize the integrated development of various energy types and improve the overall energy utilization efficiency of the whole society. Break barriers between energy sector and other sectors. Although the energy sector is the largest carbon dioxide emitter, construction, industry, transportation and other emissions are also a lot. So, it's not just one sector that's going to be carbon neutral, it's going to be a whole bunch of other industries. Break barriers between different subjects. Carbon neutrality involves different entities including government, enterprises, and individuals, each of which plays a vital role. The realization of carbon neutrality requires the consensus of the whole nation and actions of the 
whole society. New Zealand will allow factors of production and resources to flow freely in a wider range and give play to the role of all market players.

\section{References}

1. Abnett, K. (2021). EU's carbon border tariff to target steel, cement, power - draft. https://www.reuters.com/business/sustainable-business/eus-carbon-border-tariff-target-steel-cementpower-draft-2021-06-03/

2. Abnett, K. (2021). Shipping, heating and cars targeted in EU carbon market revamp. https://www.reuters.com/business/sustainable-business/eu-drafts-plan-tighten-carbon-marketexpand-it-shipping-cars-heating-2021-06-30/

3. Bloomberg News. (2021). China is formulating a hydrogen plan but its timing is uncertain. https://www.bloomberg.com/news/articles/2021-04-23/china-is-formulating-a-hydrogen-plan-butits-timing-is-uncertain

4. Cevik, S., \& Jalles, J. (2020a). Feeling the heat: climate shocks and credit ratings. IMF Working Paper No. 20/286. Washington, DC: International Monetary Fund.

5. Cevik, S., \& Jalles, J. (2020b). This changes everything: climate shocks and sovereign bonds. IMF Working Paper No. 20/79. Washington, DC: International Monetary Fund.

6. Cevik, S., \& Jalles, J. (2020c). An apocalypse foretold: climate shocks and sovereign defaults. IMF Working Paper No. 20/231. Washington, DC: International Monetary Fund.

7. Energy Resources Aotearoa. (2021). New Zealand's energy mix. https://www.energymix.co.nz/ourconsumption/new-zealands-consumption/

8. European Commission. (2021). Recovery plan for Europe. https://ec.europa.eu/info/strategy/recovery-plan-europe_en\#relatedlinks

9. Government of the United Kingdom. (2020). Government launches new £40 million Clean Growth Fund to supercharge green start-ups. https://www.gov.uk/government/news/government-launchesnew-40-million-clean-growth-fund-to-supercharge-green-start-ups

10. Imperial College Business School, SOAS University of London. (2018). Climate change and the cost of capital in developing countries. Executive Summary.

11. Imperial College London, London School of Economics. (2021). How will acting on climate change affect the economy. https://www.imperial.ac.uk/grantham/publications/climate-change-faqs/howwill-acting-on-climate-change-affect-the-economy/

12. Klusak, P., Agarwala, M., Burke, M., Kraemer, M., \& Mohaddes, K. (2021). Rising temperatures, falling ratings: The effect of climate change on sovereign creditworthiness. Bennet Institute Working Paper

13. McKinsey. (2019). Global energy perspective 2019: Reference case. https://www.mckinsey.com/ /media/mckinsey/industries/oil\%20and\%20gas/our\%20insights/global $\% 20$ energy\%20perspective\%202019/mckinsey-energy-insights-global-energy-perspective-

2019_reference-case-summary.ashx

14. Morgan, S. (2020). Commission chews over changes to aviation emissions rules. https://www.euractiv.com/section/aviation/news/eu-commission-chews-over-changes-to-aviationemissions-rules/

15. Natural Resources Canada. (2020). Hydrogen strategy for Canada - seizing the opportunities for hydrogen - a call to action. https://www.nrcan.gc.ca/sites/www.nrcan.gc.ca/files/environment/hydrogen/NRCan_HydrogenStrategy-Canada-na-en-v3.pdf

16. Obayashi, Y. (2020). Japan aims to set up commercial hydrogen fuel supply chain by 2030. https://www.reuters.com/article/us-japan-energy-hydrogen-idUSKBN2700PM

17. OECD. (2021). OECD science, technology and innovation outlook 2021: Times of crisis and opportunity. Paris, France: OECD Publishing. doi:10.1787/75f79015-en.

18. Paris Agreement to the United Nations Framework Convention on Climate Change. (2015). Treaties and Other International Acts Series. No. 16-1104.

19. Refinitiv (2021). Power prices surge in Japan. https://www.refinitiv.com/perspectives/marketinsights/power-prices-surge-in-japan/ 
20. Rădulescu, D., \& Pascu, A. (2020). European Union: the European Green Deal Investment Plan. https://www.mondaq.com/economic-analysis/1015114/the-european-green-deal-investment-plan

21. Stein, J., Eilperin, J., Laris, M., \& Room, T. (2021). White House unveils $\$ 2$ trillion infrastructure and climate plan, setting up giant battle over size and cost of government. https://www.washingtonpost.com/us-policy/2021/03/31/biden-infrastructure-climate-plan/

22. JD Supra. (2020). The EU hydrogen strategy - another remarkable step towards creating a hydrogen industry on European-wide level. https://www.jdsupra.com/legalnews/the-eu-hydrogen-strategyanother-62174/

23. Watson Farley \& Williams. (2021). The German hydrogen strategy. https://www.wfw.com/articles/the-german-hydrogen-

strategy/\#: :text=In\%20June\%202020\%2C\%20Germany\%20presented,hydrogen\%20strategy\%20(N HS)\%C2\%B9.\&text=Finally\%2C\%20on\%201\%20January\%202021,industrial\%20usage\%20of\%20 green $\% 20$ hydroge

24. The White House. (2021a). FACT SHEET: The American jobs plan. https://www.whitehouse.gov/briefing-room/statements-releases/2021/03/31/fact-sheet-the-americanjobs-plan/

25. The White House. (2021b). Leaders Summit on Climate summary of proceedings. https://www.whitehouse.gov/briefing-room/statements-releases/2021/04/23/leaders-summit-onclimate-summary-of-proceedings/

26. van Soest HL, den Elzen MGJ, van Vuuren DP. (2021). Net-zero emission targets for major emitting countries consistent with the Paris Agreement. Nat Commun 12, 2140

27. Xi, J. (2020). Statement at the General Debate of the 75th Session of the United Nations General Assembly. https://baijiahao.baidu.com/s?id=1678546728556033497\&wfr=spider\&for=pc

28. [AEMO] Australian Energy Market Operator. (2016). Update report: Black system event in South Australia on 28 September 2016. https://apo.org.au/node/68445

29. [CLEW] Clean Energy Wire. (2020). What German households pay for power. https://www.cleanenergywire.org/factsheets/what-german-households-pay-power

30. [MfE] Ministry for the Environment. (2021). Latest annual inventory of greenhouse gases in New Zealand released. $2021 \mathrm{Apr}$ 13. https://environment.govt.nz/news/latest-annual-inventory-ofgreenhouse-gases-in-new-zealand-released-13-april-2021/

31. [MoEF South Korea] Republic of Korea Ministry of Economy and Finance. (2020). Government releases an English booklet on the Korean New Deal. https://english.moef.go.kr/pc/selectTbPressCenterDtl.do?boardCd=N0001\&seq=4948

32. [ICAP] International Carbon Action Partnership. (2021). Emissions trading worldwide: ICAP status report 2021. Berlin: International Carbon Action Partnership.

33. [ICPDR] International Commission for the Protection for the Danube River (Austria). (2020). NextGenerationEU: State of the Union address reveals New Green Funds for the EU. https://www.icpdr.org/main/nextgenerationeu-state-union-address-reveals-new-green-funds-eu

34. [IEA] International Energy Agency. (2019). World energy outlook 2019 report extract electricity. https://www.iea.org/reports/world-energy-outlook-2019/electricity

35. [IEA] International Energy Agency. (2020). 40 Ministers from around the world gather to address the world's energy and climate challenges. https://www.iea.org/news/40-ministers-from-around-theworld-gather-to-address-the-world-s-energy-and-climate-challenges

36. [IRENA] International Renewable Energy Agency. (2017). Perspectives for the energy transition: Investment needs for a low-carbon energy system. https://www.irena.org//media/Files/IRENA/Agency/Publication/2017/Mar/Perspectives_for_the_Energy_Transition_2017. pdf?la=en\&hash=56436956B74DBD22A9C6309ED76E3924A879D0C7

37. [IRENA] International Renewable Energy Agency. (2021). Renewable power generation costs in 2020. https://www.irena.org//media/Files/IRENA/Agency/Publication/2021/Jun/IRENA_Power_Generation_Costs_2020.pdf

38. [State Department] U.S. Department of State. (2021). John Kerry, Special Presidential Envoy for Climate. https://www.state.gov/biographies/john-kerry/

39. [USTR] The Office of the United States Trade Representative (2021). The President's 2021 Trade Policy Agenda. 
https://ustr.gov/sites/default/files/files/reports/2021/2021\%20Trade\%20Agenda/Online\%20PDF\%20 2021\%20Trade\%20Policy\%20Agenda\%20and\%202020\%20Annual\%20Report.pdf 